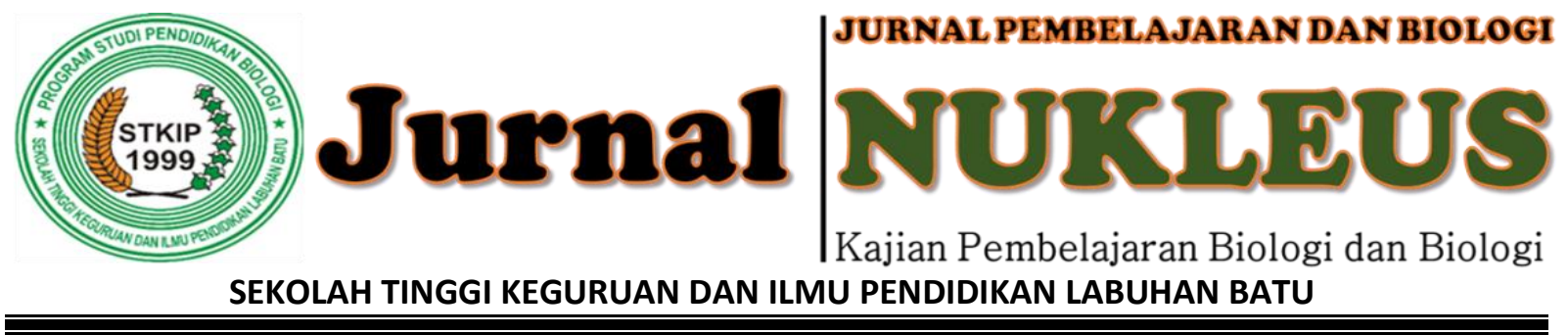

\title{
PENGARUH METODE PEMBELAJARAN PETA KONSEP (MIND MAPPING) TERHADAP HASIL BELAJAR BIOLOGI SISWA KELAS XI PADA MATERI SEL DI MADRASAH ALIYAH SWASTA ISLAMIYAH SUBULUSSALAM SUMBEREJO
}

Siti Suharni Simamora

Pendidikan Biologi, STKIP Labuhanbatu

Jalan SM Raja No 126 A, Aek Tapa, Rantauprapat`email: sitisuharnisimamora72@gmail.com.

\section{Info Artikel}

Riwayat Artikel:

Diterima Januari 2018

Disetujui Februari 2018 Dipublikasikan Februari 2018

\begin{abstract}
Abstrak
Penelitan ini bertujuan untuk mengetahui Pengaruh Metode Pembelajaran Peta Konsep (Mind Mapping) terhadap Hasil Belajar Biologi Siswa Kelas XI padaMateri SelDi Madrasah Aliyah Swasta Islamiyah Subulussalam Sumberejo T.P 2017/2018. Metode penelitian ini bersifat kuasi eksperimen. Populasi dalam penelitian ini adalah seluruh siswa kelas XI IPA Madrasah Aliyah Swasta Islamiyah Subulussalam Sumberejo Tahun Pembelajaran 2017-2018 yang berjumlah total 62 siswa yang terbagi ke dalam 2 kelas paralel. Sampel dalam penelitian ini merupakan populasi penelitian. Desain penelitian ini adalah pretest-posttest control group design, yaitu: Kelas pertama diajarkan dengan Metode Pembelajaran Peta Konsep (Mind Mapping) jumlah 32 siswa, dan kelas kedua diajarkan dengan pembelajaran konvensional, yakni ceramah-tanya jawab jumlah 30 siswa. Instrumen penelitian berupa tes hasil belajar siswa berjumlah 36 soa pilihan berganda yang telah valid. Teknik analisis data pada penelitian ini menggunakan uji $t$ dengan melihat perbandingan hasil belajar siswa pada taraf signifikan $a=0,05$. Hasil penelitian ini diperoleh bahwa: Terdapat terdapat Pengaruh Metode Pembelajaran Peta Konsep (Mind Mapping) terhadap Hasil Belajar Biologi Siswa padaMateri Sel Di Madrasah Aliyah Swasta Islamiyah Subulussalam Sumberejo, yaitu: hasil belajar siswa yang diajarkan dengan Metode Pembelajaran Peta Konsep (Mind Mapping) dengan nilai rata-rata hasil belajar siswa sebesar = 77,18 lebih baik dibanding dengan hasil belajar siswa yang diajarkan dengan pembelajaran konvensional dengan nilai rata-rata hasil belajar siswa sebesar $=67,75$.
\end{abstract}

Kata Kunci: Metode Pembelajaran Peta Konsep, Konvensional, Hasil Belajar

\section{PENDAHULUAN}

Belajar merupakan proses yang kompleks yang terjadi pada setiap orang disepanjang hidupnya. Dalam proses belajar melibatkan adanya interaksi antara seseorang dengan lingkungan sekitarnya. Oleh karena itu, belajar dapat terjadi kapan saja dan dimana saja.Salah satu pertanda seseorang itu telah mengalami belajar adalah adanya perubahan tingkah laku pada diri seseorang yang disebabkan oleh terjadinya perubahan pada tingkat pengetahuan, keterampilan, atau sikapnya (Arsyad, 2007). Maka proses dalam belajar merupakan peristiwa penting dalam penyampaian materi pelajaran kepada para siswa dengan cara yang baik dan tepat yang disebut dengan proses pembelajaran.

Proses pembelajaran yang selama ini diselenggarakan di sekolah, tidak lain bertujuan untuk mengarahkan perubahan tingkah laku siswa secara sederhana, baik dalam aspek pengetahuan, keterampilan, maupun sikap. Sebagaimana dikemukakan oleh Hamalik (2008) menyatakan bahwa belajar adalah proses kegiatan belajar mengajar, dimana dalam proses tersebut merupakan proses penyampaian pengetahuan yang akan diberikan kepada siswa dengan baik, benar dan tepat sesuai dengan tujuan pembelajaran yang diinginkan, bukan hanya sekedar mencapai suatu hasil atau tujuannya saja. Namun dalam dunia pendidikan di Indonesia tujuan merupakan faktor prioritas yang ingin dicapai tanpa melihat suatu proses bagaimana penyampaian pengetahuan itu dapat diterima oleh para peserta didik di sekolah. Proses pembelajaran merupakan faktor yang sangat penting untuk diketahui bagaimana siswa memperoleh pengetahuannya khususnya mata pelajaran biologi di dalam kelas. Karena belajar bukan hanya untuk mengingat akan apa yang telah terjadi tetapi belajar mengandung makna yang lebih luas yakni mengalami proses belajar itu sendiri. Oleh sebab itu, pembelajaran adalah proses interaksi peserta didik dengan pendidik dan sumber belajar pada suatu lingkungan belajar.Pembelajaran yang dimaksud adalah pembelajaran yang berkualitas sangat tergantung dari motivasi pelajar dan 
kreatifitas pengajar untuk mencapai keberhasilan pencapaian target belajar (Dimyati dan Mudjiono, 1999).

Peran guru tidak hanya sekedar mengajar melainkan membelajarkan peserta didik agar mau belajar. Tugas guru dalam proses pembelajaran, disamping menyampaikan informasi, ia juga bertugas mendiagnosis kesulitan belajar siswa, menyeleksi materi ajar, mensupervisi kegiatan belajar, menstimulasi kegiatan belajar siswa, memberikan bimbingan belajar, mengembangkan dan menggunakan model dan metode (Arends, 2008). Maka peran guru memliki peranan penting dalam menyampaikan pengetahuan berupa materi biologi kepada para siswa dengan baik dan benar serta dengan proses pembelajaran yang tepat pula. Akan tetapi pembelajaran pada saat ini masih berorientasi kepada guru (teacher oriented), sehingga hal ini memberikan dampak kepada para siswa kurang untuk diberi kesempatan dalam menyelesaikan suatu bentuk permasalahan materi pembelajaran ketika proses pembelajaran berlangsung yang berdampak pula pada rendahnya motivasi belajar siswa dan minat belajar siswa karena ketika pada proses pembelajaran tersebut siswa kurang dapat dengan bebas dalam mengembangkan kemampuan berpikirnya di dalam kelas. Proses yang demikian ini juga terjadi pada Madrasah Aliyah Swasta Islamiyah Subulussalam Sumberejo, dimana Guru biologi dalam proses pembelajaran biologi masih melakukan proses pembelajaran berupa ceramah tanya jawab yang hanya terfokus pada guru di depan kelas, dan juga cenderung lebih sering memberikan informasi atau cerita tentang pengetahuan biologi. Pembelajaran seperti ini menyebabkan siswa tidak termotivasi untuk belajar biologi dan menjadi salah satu faktor yang menyebabkan rendahnya hasil belajar siswa pada bidang studi biologi.Belajar dengan menggunakan metode dimana siswa hanya menerima informasi dan konsep biologi menjadikan biologi kurang bermakna bagi siswa.Hal ini memberikan rendahnya minat dan motivasi belajar siswa di dalam kelas.

Maka berdasarkan uraian tersebut, perlu adanya suatu penelitian yang bertujuan untuk membangun motivasi siswa dan mendukung cara siswa dalam menyelesaikan proses pembelajarannya kearah yang lebih baik kedepannya, yakni dengan metode pembelajaran peta konsep. Peta konsep merupakan suatu cara untuk merepresentasikan pemahaman konseptual anak dan mengamati perubahan konsep yang membentuk pemahan anak (Novak dan Canas, 2006) dan untuk merepresentasikan kerangka kerja dalam membentuk hubungan antar konsep (Broggy dan McClelland, 2008).

Peta Konsep merupakan salah satu metode pembelajaran berbasis grafis (Zeilik, 1998). Peta
Konsep merupakan diagram hirarkis dua dimensi yang menggambarkan struktur pengetahuan mengenai disiplin keilmuan sebagaimana yang dilihat siswa, pelatih, atau seorang ahli di lapangan (Zeilik, 1998; Broggy dan McClelland, 2008). Peta Konsep terdiri dari label konsep berbentuk oval atau kotak yang saling berhubungan. Dengan membaca peta dari atas ke bawah, guru dapat mengetahui cara siswa dalam melihat suatu topik keilmuan, menguji pemahaman yang valid dan miskonsepsi yang dimiliki siswa, dan menilai kompleksitas struktural hubungan antar gambar yang dibuat siswa.

\section{METODE PENELITIAN}

Metode penelitian ini bersifat kuasi eksperimen.Populasi dalam penelitian ini adalah seluruh siswa kelas XI IPA Madrasah Aliyah Swasta Islamiyah Subulussalam Sumberejo Tahun Pembelajaran 2017-2018 yang berjumlah total 62 siswa yang terbagi ke dalam 2 kelas paralel. Sampel dalam penelitian ini merupakan populasi penelitian.Desain penelitian ini adalah pretestposttest control group design, yaitu: Kelas pertama diajarkan dengan Metode Pembelajaran Peta Konsep (Mind Mapping) jumlah 32 siswa, dan kelas kedua diajarkan dengan pembelajaran konvensional, yakni ceramah-tanya jawab jumlah 30 siswa. Instrumen penelitian berupa tes hasil belajar siswa berjumlah 36 soal pilihan berganda yang telah valid. Teknik analisis data pada penelitian ini menggunakan uji t dengan melihat perbandingan hasil belajar siswa pada taraf signifikan $a=0,05$.

\section{HASIL PENELITIAN DAN PEMBAHASAN HASIL \\ Pretes Siswa}

Dari penelitian yang telah dilakukan diperoleh pretes siswa yang diajarkan dengan metode pembelajaran Peta Konsep dengan jumlah 32 siswa diperoleh data nilai rata-rata pretes siswa sebesar $=54,06$ dengan nilai terendah $=35,00$; nilai tertinggi $=72,50$; standar deviasi $=9,28$. Pretes siswa yang diajarkan dengan pembelajaran konvensional dengan jumlah 30 siswa diperoleh data nilai rata-rata pretes siswa sebesar $=50,25$ dengan nilai terendah $=37,50$; nilai tertinggi $=$ 62,50 ; standar deviasi $=9,31$.

\section{Postes Hasil Belajar Siswa}

Dari penelitian yang telah dilakukan diperoleh hasil belajar siswa yang diajarkan dengan metode pembelajaran Peta Konsep dengan jumlah 32 siswa diperoleh data nilai rata-rata hasil belajar siswa sebesar $=77,18$ dengan nilai terendah $=57,50$; nilai tertinggi $=92,50$; standar deviasi $=8,41$. Hasil belajar siswa yang diajarkan 
dengan pembelajaran konvensional dengan jumlah 30 siswa diperoleh data nilai rata-rata hasil belajar siswa sebesar $=67,75$ dengan nilai terendah $=$ 57,50 ; nilai tertinggi $=82,50$; standar deviasi $=$ 6,37 .

\section{PENGUJIAN HIPOTESIS}

Pengaruh Metode Pembelajaran Peta Konsep (Mind Mapping) terhadap Hasil Belajar Biologi Siswa padaMateri Sel Di Madrasah Aliyah Swasta Islamiyah Subulussalam Sumberejo.

Berdasarkan hasil uji hipotesis diperoleh bahwa terdapat Pengaruh Metode Pembelajaran Peta Konsep (Mind Mapping) terhadap Hasil Belajar Biologi Siswa Kelas XI padaMateri SelDi Madrasah Aliyah Swasta Islamiyah Subulussalam Sumberejo T.P 2017/2018. Hal ini dapat dilihat bahwa nilai thitung sebesar 4,767 lebih besar dari nilai t-tabel dengan jumlah total siswa dari kedua kelas, yaitu: kelas eksperimen dengan kelas kontrol diperoleh total siswa 62 dengan taraf kepercayaan 0,05 maka t-tabelnya sebesar 2,000. Dengan demikian t-hitung $(4,767)$ lebih besar dari t-tabel $(2,000)$, maka hasil belajar siswa yang diajarkan dengan Metode Pembelajaran Peta Konsep (Mind Mapping) dengan nilai rata-rata hasil belajar siswa sebesar = 77,18 lebih baik dibanding dengan hasil belajar siswa yang diajarkan dengan pembelajaran konvensional dengan nilai rata-rata hasil belajar siswa sebesar $=67,75$.

\section{PEMBAHASAN}

Pengaruh Metode Pembelajaran Peta Konsep (Mind Mapping) terhadap Hasil Belajar Biologi Siswa padaMateri Sel Di Madrasah Aliyah Swasta Islamiyah Subulussalam Sumberejo.

Berdasarkan hasil uji hipotesis diperoleh bahwa terdapat Pengaruh Metode Pembelajaran Peta Konsep (Mind Mapping) terhadap Hasil Belajar Biologi Siswa Kelas XI padaMateri SelDi Madrasah Aliyah Swasta Islamiyah Subulussalam Sumberejo T.P 2017/2018, yaitu: hasil belajar siswa yang diajarkan dengan Metode Pembelajaran Peta Konsep (Mind Mapping) dengan nilai rata-rata hasil belajar siswa sebesar $=77,18$ lebih baik dibanding dengan hasil belajar siswa yang diajarkan dengan pembelajaran konvensional dengan nilai rata-rata hasil belajar siswa sebesar $=67,75$. Hal ini disebabkan karena pada Proses Pembelajaran Peta Konsep (Mind Mapping) siswa akan selalu terpacu untuk menemukan hubungan antara konsepkonsep, meski di tiap tingkatan, dari yang paling umum hingga tingkat yang paling spesifik. Dengan peta konsep, siswa membangun pemahaman mereka secara konseptual, sehingga mereka dapat meraih hasil belajar kognitif yang lebih tinggi dalam pembelajaran yang bermakna.Perbandingan Hasil Belajar Siswa yang Diajarkan dengan Metode Pembelajaran Peta Konsep (Mind Mapping) dengan
Pembelajaran Konvensional dapat dilihat pada Gambar 4.1.

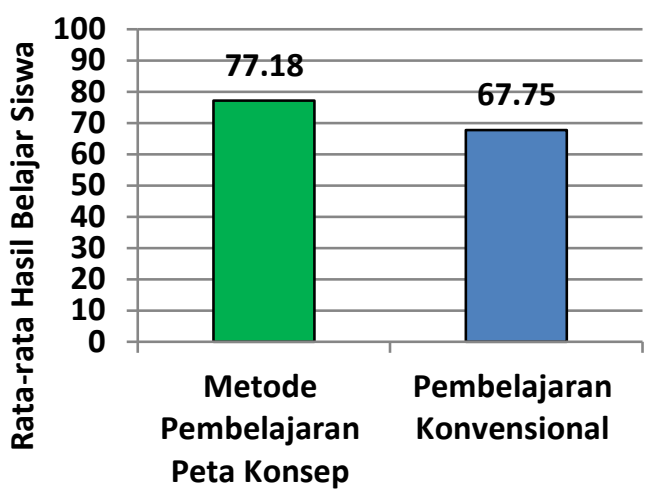

Pembelajaran yang Digunakan

Gambar 4.1.Perbandingan Hasil Belajar Siswa yang Diajarkan dengan Metode Pembelajaran Peta Konsep (Mind Mapping) dengan Pembelajaran Konvensional

Hal ini juga dinyatakan oleh Novak dan Canas (2007) bahwa Pembelajaran Peta Konsep merupakan suatu cara untuk merepresentasikan pemahaman konseptual anak dan mengamati perubahan konsep yang membentuk pemahaman anak dan untuk merepresentasikan kerangka kerja dalam membentuk hubungan antar konsep.

Peta Konsep merupakan diagram yang saling berhubungan secara hirarkis dan dua dimensi yang menggambarkan struktur pengetahuan dalam disiplin ilmu untuk dilihat oleh siswa, guru atau ahli dalam suatu bidang atau subbidang (Zeilik, 1998). Peta terdiri dari label konsep, masing-masing dibungkus dalam kotak atau oval; serangkaian garis penghubung antar label, dan penghubung antara organisasi umum, inklusif kepada organisasi yang lebih khusus. Dengan membaca peta dari atas ke bawah, seorang pengajar dapat (1) memperoleh informasi tentang cara siswa melihat topik ilmiah; (2) menguji pemahaman siswa; dan (3) menilai kompleksitas struktural hubungan gambaran yang dibuat siswa (Broggy dan McClelland, 2008).

Corebima (2007) menyatakan bahwa dalam pembelajaran dengan peta konsep, siswa dapat membangun hubungan antar konsep-konsep materi pokok, secara individu maupun kelompok. Dengan demikian, melalui pembelajaran peta konsep, siswa akan selalu terpacu untuk menemukan hubungan antara konsep-konsep, meski di tiap tingkatan, dari yang paling umum hingga tingkat yang paling spesifik. Dengan peta konsep, siswa membangun pemahaman mereka secara konseptual pada materi pembelajaran biologi, sehingga mereka dapat meraih hasil belajar kognitif siswa yang lebih tinggi pula dalam pembelajaran yang bermakna dan proses pembelajaran yang berkesan bagi para siswa. 


\section{KESIMPULAN}

Berdasarkan hasil penelitian dan analisis data, maka dapat diambil simpulan sebagai berikut: Terdapat Pengaruh Metode Pembelajaran Peta Konsep (Mind Mapping) terhadap Hasil Belajar Biologi Siswa Kelas XI padaMateri SelDi Madrasah Aliyah Swasta Islamiyah Subulussalam Sumberejo T.P 2017/2018, yaitu: hasil belajar siswa yang diajarkan dengan Metode Pembelajaran Peta Konsep (Mind Mapping) dengan nilai rata-rata hasil belajar siswa sebesar $=77,18$ lebih baik dibanding dengan hasil belajar siswa yang diajarkan dengan pembelajaran konvensional dengan nilai rata-rata hasil belajar siswa sebesar $=67,75$.

\section{DAFTAR PUSTAKA}

Abdurrahman, M. 2003. Pendidikan Anak Berkesulitan Belajar. Jakarta: Rineka Cipta.

Arends, Richard, I. 2008. Learning to Teach.Belajar untuk Mengajar. Edisi Dua, (Penerjemah: Helly Prayitno Soetjipto dan Sri Mulyantino Soetjipto). Yogyakarta: Pustaka Pelajar.

Arikunto, S. 2006. Prosedur Penelitian (Suatu Pendekatan Praktik Edisi Revisi VI). Jakarta: Rineka Cipta.

Arsyad, A. 2007.Media Pembelajaran. Jakarta: Raja Grafindo Persada.

Bloom, B, S. 1956.Taxonomy of Educational Objective: Hand Book I: Cognitive Domain. New York.

Broggy, J., \& McClelland, G. 2008. Undergraduate Students' Attitudes Towards Physics After A Concept Mapping Experience.Proc.Of the Third
Int. Conference on Concept Mapping. A. J. Canas, P. Rieska, M. Ahlberg \& J. D. Novak Estonia \& Helsinki, Finland: Eds. Tallinn.

Corebima, A.D. 2007. Review On: Learning Strategies Having Bigger Potency To Empower Thinking Skill And Concept Gaining Of Lower Academic Students. Malang: Malang State University.

Dimyati dan Mudjiono. 1999. Belajar dan Pembelajaran.Jakarta: Rineka Cipta.

Hamalik, O. 2008.Kurikulum dan Pembelajaran.Jakarta: Bumi Aksara.

Novak, J. D., \& Canas, A. J. 2007. The Origins of the Concept Mapping Tool and the Continuing Evolution of the Tool.Information Visualization Journal, 5: 175-184.

Purwanto, M, N. 2000. Psikologi Pendidikan. Bandung: Remaja Rosdakarya.

Slameto. 2003. Belajar dan Faktor-faktor yang Mempengaruhinya. Jakarta: Rineka Cipta.

Slavin, R, E. 2008. Cooperative Learning: Teori, Riset, dan Praktik, Terjemahan Nurulita Yusron. Bandung: Nusa Media.

Sudjana, N. 2001.Penilaian Hasil dan Proses Hasil Belajar.Bandung: Remaja Rosdakarya.

Sudjana, N., dan Rivai A. 2002. Media Pengajaran. Bandung: Sinar Baru Algensindo.

Syamsuri, Istamar, 2007. Biologi 2A. Jakarta: Erlangga.

Widodo, A. 2006. Profil Pertanyaan Guru dan Siswa dalam Pembelajaran Sains: The Feature Of Teachers' and Students' Questions In Science Lessons, Vol. 4 , No. 2, http://isjd.pdii.lipi.go.id/admin/jurnal/42061391 48.pdf.

Zeilik, M. 1998. Concept Mapping.Departement of Physics and Astronomy. Meksiko: University of New Mexico. 